\title{
Radioiodination of Zaleplon and Its in-vivo Biologic Behavior in Mice: An Imaging Probe for Brain
}

\author{
A. M. Amin ${ }^{1}$, S. E. Soliman' ${ }^{2}$, H. A. El-Aziz ${ }^{2}$ \& S. A. Abo El-Enein ${ }^{3}$ \\ ${ }^{1}$ Labeled Compounds Department, Hot Labs Center, Atomic Energy Authority, Cairo, Egypt \\ ${ }^{2}$ Radioisotope Production Project, Atomic Energy Authority, Cairo, Egypt \\ ${ }^{3}$ Chemistry Department, Faculty of Science, Ain Shams University, Cairo, Egypt \\ Correspondence: A. M. Amin, Labeled Compounds Department, Hot Labs Center, Atomic Energy Authority, \\ P.O. Box 13759, Cairo, Egypt. E-mail: ab_amin@hotmail.com
}

Received: May 28, 2013 Accepted: July 3, 2013 Online Published: November 21, 2013

doi: 10.5539/ijc.v6n1p17 URL: http://dx.doi.org/10.5539/ijc.v6n1p17

\begin{abstract}
The hypnotic zaleplon displays novel receptor selectivity different from other benzodiazepine receptor ligands in clinical use. Zaleplon was successfully labeled with iodine- 125 via electrophilic substitution reaction producing ${ }^{125}$ I-Zaleplon tracer. This reaction proceeds well in acidic $\mathrm{pH}$ of value equal to 4 , due to the solubility of the Zaleplon in this acidic pH value. Chloramine-T (CAT) was used as oxidizing agent, at low amount of (CAT) $(25-50 \mu \mathrm{g})$ the radiochemical yield of the labeled compound was low $(80 \%)$ while at $200 \mu \mathrm{g}$, an optimum yield $(97 \%)$ was obtained.Heating the reaction mixture to $40{ }^{\circ} \mathrm{C}$ for $15 \mathrm{~min}$ was recommended to get a yield more than $97 \%$, but heating for longer time causes a decomposition of the labeled Zaleplon. The in-vitro stability of ${ }^{125}$ I-Zaleplon was determined along 24 hours; the data confirms that ${ }^{125}$ I-Zaleplon tracer was stable along eight hours without the detection of any by-products in the reaction mixture. The biodistribution data of the labeled Zaleplon shows rapid blood clearance passes through the blood brain barrier (BBB) and the activity detected in the brain exceeds $4.4 \%$ at $1 \mathrm{~h}$ post injection.
\end{abstract}

Keywords: radioiodination, Iodine-125, Zaleplon, receptor selectivity, brain imaging

\section{Introduction}

Brain imaging represents a potent tool to characterize biomarkers, biological traits that are pathognomonic for specific neurological,and neuropsychiatric disorders. Positron emission tomography (PET) and single photon emission computed tomography (SPECT) are imaging techniques used to identify alterations in the density and distribution of neurotransmitters, neuroreceptors, and transporters in specific regions of the brains of people with these disorders (Wong, Gründer, \& Brasic, 2007). The interactions between transporters/receptors and neurotransmitters play a key role in the diagnosis and treatment of neuropsychiatric disorders (Heiss \& Herholz, 2006). Radiotracers must fulfill several criteria to be successful for PET or SPECT imaging: including readily labeled with appropriate radionuclide and the labeled radiotracer being stable in vivo and nontoxic; sufficient affinity and high selectivity for the specific receptor combined with low nonspecific binding to brain tissue not containing the receptor of interest; rapid permeation through the blood-brain barrier permitting high access of tracers to receptors, as well as allowing high initial brain uptake and fast clearance of the activity from the brain (Shen, Liao, \& Tseng, 2012).

Hypnotic drugs are often prescribed in primary care for insomnia (Siriwardena, Apekey, Tilling, Dyas, Middleton, \& Orner, 2010; Ramakrishnan \& Scheid, 2007; Barbera \& Shapiro, 2005; Dundar, Dodd, Strobl, Boland, Dickson, \& Walley, 2004). Despite a reduction in prescribing of benzodiazepine hypnotics in the past decade, hypnotic use and costs remain high because of the introduction and increase in use of $\mathrm{Z}$ drugs (Siriwardena, Qureshi, Gibson, Collier, \& Latham, 2006), a group of non-benzodiazepine hypnotic drugs (including eszopiclone, zaleplon, and zolpidem), which act on the $\gamma$-aminobutyric acid (GABA) receptor andare used in the treatment of insomnia (Dooley \& Plosker, 2000). These are now the most commonly prescribed hypnotic agents worldwide. Zaleplon Figure 1 is a pyrrazolo pyrimidine hypnotic drug (Hurst \& Noble, 1999; Noguchi, Kitazumi, Mori, \& Shiba, 2004; Patat, Paty, \& Hindmarch, 2001). It interacts with $\mathrm{GABA}_{\mathrm{A}}$ receptor and also shows some pharmacological properties of benzodiazepines (Damgen \& Luddens, 1999). It also 
possesses potent anticonvulsant activity against pentylenetetrazole- and electroshock-induced convulsions (Dämgen \& Luddens, 2000). Zaleplonrecognizes $\alpha 2$ - and $\alpha 3$-receptors that additionally contain a $\beta \mathrm{j}$ and the $\gamma 3$-subunit. The hypnotic zaleplon displaysanovel receptor selectivity different from other benzodiazepine receptor ligands in clinical use (Waghmare, Pore, \& Kuchekar, 2008). Other nonclinical studies have also shown that zaleplon binds selectively to the brain omega-1 receptor situated on the alpha subunit of the $\mathrm{GABA}_{\mathrm{A}} /$ chloride ion channel receptor complex (Damgen \& Luddens, 1999).<smiles>CCN(C(C)=O)c1cccc(-c2ccnc3c(C#N)cnn23)c1</smiles>

Figure 1. Chemical structure of zaleplon

\section{Material and Method}

Zaleplon, m.wt. $=305.3$, and Chloramine-T (N-chloro p-toluene sulphonamide sodium salt) m.W. 227.65 were purchased from Aldrich Chemical Company. Radioactive iodine-125 (Na125I ) was purchased from Nordion, Canada.

\subsection{Animals}

White male Swiss albino mice, weighing 30-35 g were used for experiments. Mice were obtained from the Institute of Ophthalmology (Giza, Egypt). The animals were kept under suitable laboratory conditions throughout the period of investigation.

\subsection{Method}

\subsubsection{Radioiodination}

In a screw caped reaction vial, an appropriate ethanolic solution of the substrate with the desired concentration and a suitable activity of $\mathrm{Na}^{125} \mathrm{I}(7-15 \mathrm{MBq})$ were added, followed by the addition of the oxidizing agent (CAT). The $\mathrm{pH}$ value of the reaction mixture $(\mathrm{pH} 2-11)$ was varied using different buffer systems. The reaction was allowed to proceed for a chosen interval of time at different temperatures, after which the reaction was terminated by the addition of $50 \mu \mathrm{l}$ of aqueous solution of $\mathrm{Na}_{2} \mathrm{~S}_{2} \mathrm{O}_{5}(20 \mathrm{mg} / \mathrm{ml})$ to ensure that all the unreacted iodine is in a reduced form before chromatographic analysis.

\subsubsection{Determination of Radiochemical Yield}

The radiochemical yield was determined using the electrophoresis technique (EC 3000P, series 90 programmable, E-C apparatus corporation) power unit and a chamber supply unit using cellulose acetate strips. The application point was indicated on the strip, moistened by buffer solution ( $0.02 \mathrm{M}$ phosphate buffer of $\mathrm{pH} 7)$ and putted in the electrophoresis chamber after sample application. Standing time for one and half hours at 300 volts, then the developed strips were dried, cut into $1 \mathrm{~cm}$ segments and counted by a well-type $\mathrm{NaI}(4 \% \mathrm{Tl})$ scintillation $\gamma$-counter.

\subsubsection{Determination of Radiochemical Purity}

The radiochemical purity of the ${ }^{125}$ I-Zaleplon was determined by HPLC. The reaction mixture $(10 \mu l)$ was injected into the reversed phase RP-18 column of the HPLC system. The U.V spectrophotometer detector was adjusted to the wave length $232 \mathrm{~nm}$. The column after loading was eluted by a mixture of methanol and water (70:30) as developing solvent at flow rate $0.5 \mathrm{ml} / \mathrm{min}$. The fractions were collected and counted using $\mathrm{NaI} / \mathrm{Tl}$ 
crystal connected to SR.7 gamma counter.

\subsubsection{Determination of the Partition Coefficient}

The partition coefficient was determined by mixing ${ }^{125} \mathrm{I}$-Zaleplonwith equal volumes of 1 -octanol and phosphate buffer $(0.025 \mathrm{M}$ at $\mathrm{pH} 7.4)$ in a centrifuge tube. The mixture was vortexed at room temperature for 1 min and then centrifuged at 5,000 rpm for $5 \mathrm{~min}$. Subsequently $100 \mu \mathrm{l}$ samples from the 1-octanol and aqueous layers were pipetted into other test tubes and counted in a gamma counter. The measurement was repeated for five times. The partition coefficient value was expressed as $\log \mathrm{p}$ (Liu, 2004).

\section{Result and Discussion}

The application of Chloramine-T (CAT) is a way to achieve electrophilic radioiodination of organic molecules (Al dayel, Al Subybani, \&, El-Garhy, 1998; Bolton, 1977). In aqueous solution Chloramine-T is often discussed to slowly release hypochlorous acid $(\mathrm{HOCl})$, which oxidizes iodide under formation of an iodonium ion $\left(\mathrm{H}_{2} \mathrm{OI}^{+}\right)$. In the current study, factors affecting the labeling of Zaleplon with iodine-125 were studied to select the optimum conditions required to give the maximum radiochemical yield of ${ }^{125}$ I-Zaleplone. The labeled Zaleplon was biologically evaluated in normal mice, to elucidate its specific binding to the brain receptors.

\subsection{Effect of Zaleplon Amounts}

Different amounts of Zaleplon were dissolved in ethanol and the radioiodine-125 was added while the $\mathrm{pH}$ of the reaction mixture was kept at 4 . Labeling yield was measured at $150 \mu \mathrm{g}$ CAT as oxidizing agent when the reaction mixture was heated for $15 \mathrm{~min}$. to $40{ }^{\circ} \mathrm{C}$. The data are summarized in Figure 2. The data illustrate an increase in the yield of ${ }^{125} \mathrm{I}$-Zaleplonby increasing the amount of Zaleplon from 50 to $250 \mu \mathrm{g}$, with a maximum of (97.4\%) at $150 \mu \mathrm{g}$ Zaleplon. The radiochemical yield is not affected by the amount of Zaleplon higher than $150 \mu \mathrm{g}$. This may be attributed to the fact that $150 \mu \mathrm{g}$ of Zaleplon is enough to capture all the entire generated iodonium ions as a result of the oxidation of the radioactive iodide $\left({ }^{125} \mathrm{I}^{-}\right)$at $150 \mu \mathrm{g}$ CAT (El-Azony, El-Mohty, Killa, Seddik, \& Khater, 2009).

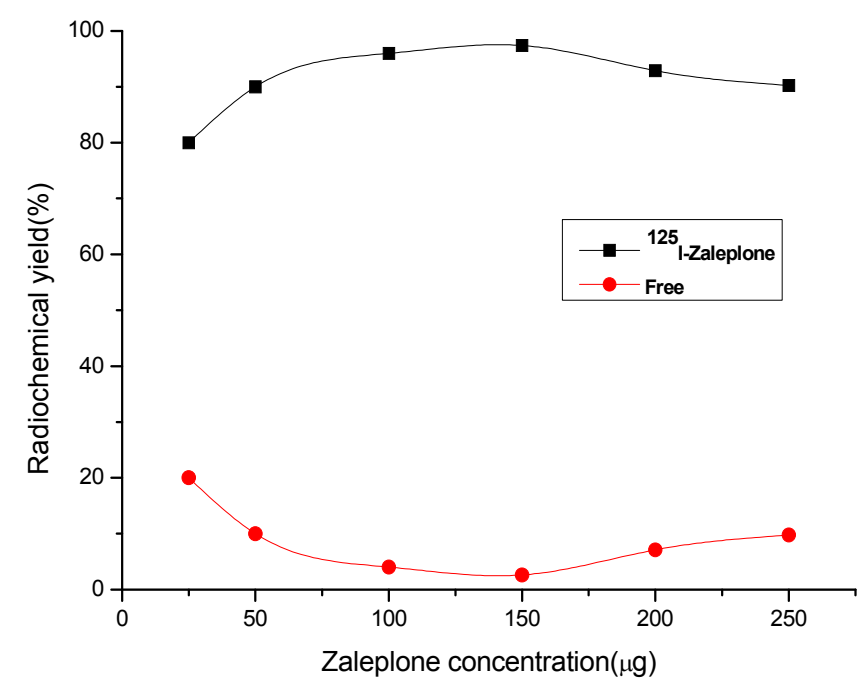

Figure 2. The radiochemical yield of ${ }^{125} \mathrm{I}$-Zaleplon as a function of substrate amount

\subsection{Effect of Chloramine-T Amount}

The effect of chloramine-T amount on the radiochemical yield of ${ }^{125}$ I-Zaleplonhas been investigated. The amount of chloramine-T is very important due to its high reactivity. The data presented in Figure 3 clearly reveal that the yield of ${ }^{125} \mathrm{I}$-Zaleplon increased by increasing the amount of chloramine-T up to $150 \mu \mathrm{g}$. Increasing the amount of chloramine-T to $250 \mu \mathrm{g}$ caused a decrease of the radiochemical yield of ${ }^{125}$ I-Zaleplon which may be due to the formation of oxidative side products (Knust, Dutschka, \& Machulla, 1999; Petzold \& Coenen, 1981). In this study, $150 \mu \mathrm{g}$ of chloramine-T was found to be the optimum concentration. 


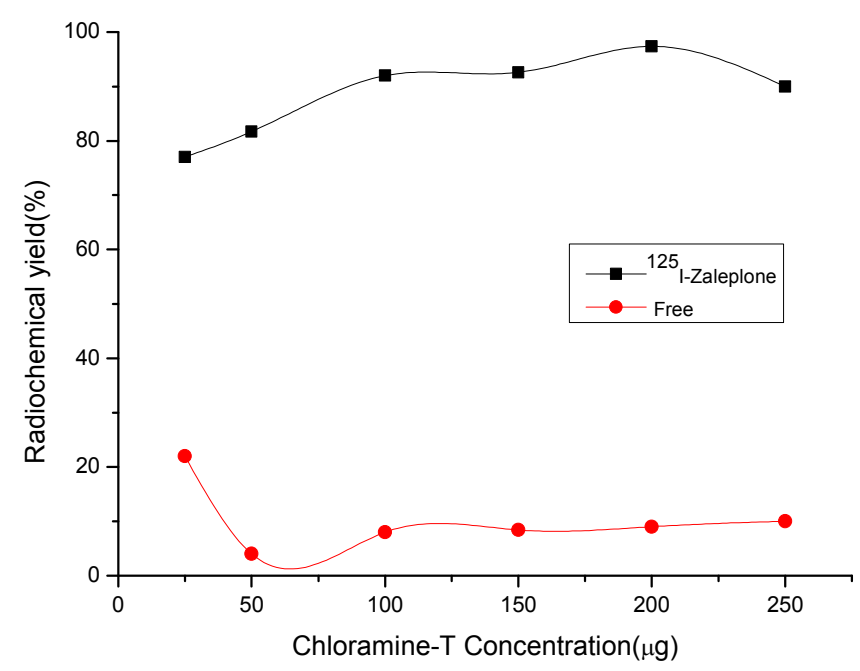

Figure 3. The radiochemical yield of $125 \mathrm{I}-$ Zaleplon as a function of chloramine-T amount

\subsection{Effect of Temperature}

The labeling reaction was done at room temperature $\left(25^{\circ} \mathrm{C}\right)$ and at higher temperatures by heating the reaction mixture at $40,60,80$ and $100{ }^{\circ} \mathrm{C}$ for different intervals of time. The data of this experiment are presented in Figure 4, that clearly show that the reaction yield was optimum $(97 \%)$ at $40{ }^{\circ} \mathrm{C}$ after 15 min reaction time. At room temperature, the labeling reaction was slow and yielded $47 \%$ after $15 \mathrm{~min}$. When the reaction temperature was increased up to 60 and $80{ }^{\circ} \mathrm{C}$, the radiochemical yields were $79 \%$ and $88 \%$, respectively, without an additional increase even after $60 \mathrm{~min}$ reaction time. Nevertheless, when the reaction temperature was increased to $100{ }^{\circ} \mathrm{C}$, the labeled Zaleplon was decomposed and reached to $20 \%$ after $5 \mathrm{~min}$ reaction time. The labeling of Zaleplon with iodine -125 at $100{ }^{\circ} \mathrm{C}$ was not efficient due to the decomposition of the labeled Zaleplon (El-Azony, 2004).

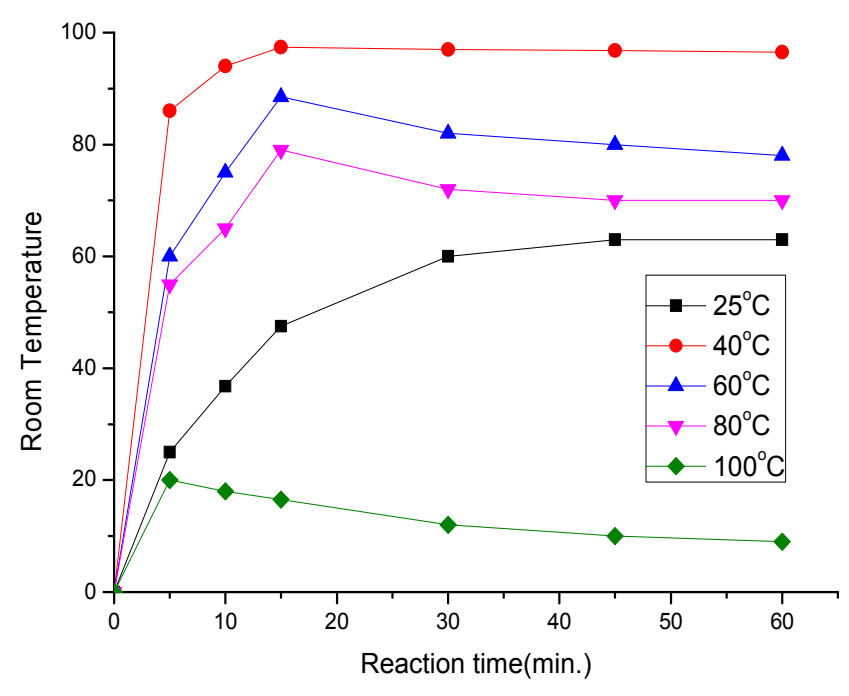

Figure 4. The radiochemical yield of ${ }^{125}$ I-Zaleplon as a function of reaction time at different temperature

\subsection{Effect of Different $p H$ Values}

The labeling process was carried out through the electrophilic substitution of $\mathrm{H}^{+}$of the benzene ring by iodonium 
ion, $\mathrm{I}^{+}$. Different buffering systems were used during this experiment to attain the required $\mathrm{pH}$ values. Citrate/citric acid, mono and di hydrogen phosphate, and bicarbonate were used to obtain the following $\mathrm{pH}$ values, $2 \& 4,7$, and $9 \& 11$, respectively. The labeling reaction proceeds well in acidic $\mathrm{pH}$ equal to 2 and 4 , giving a yield of ${ }^{125} \mathrm{I}$-Zaleplon equal to $97 \%$ as shown in Figure 5 . This may be due to ease of solubility of the Zaleplon in acidic medium. In alkaline medium of $\mathrm{pH} 11$ the yield of ${ }^{125} \mathrm{I}$-Zaleplone was $60 \%$ which is attributed to the partial solubility of the Zaleplon itself in this $\mathrm{pH}$ value.

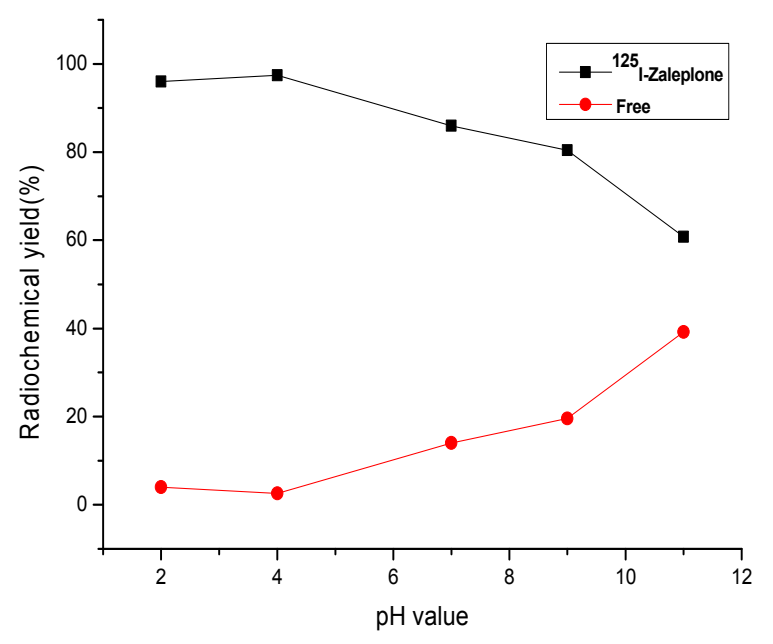

Figure 5. Effect of $\mathrm{pH}$ of the reaction medium on the percent radiochemical yield of ${ }^{125} \mathrm{I}$-Zaleplon

\subsection{Stability of ${ }^{125}$ I-Zaleplon}

The in-vitro stability of the labeled compounds is the backbone for their uses in nuclear medicine. It is very important for the labeled compounds to be stable for 8 hours or more, the time during which the patients can be injected safely. The in-vitro stability of ${ }^{125} \mathrm{I}$-Zaleplon was determined along 24 hours and the data are presented in Table 1 . The data clearly confirm the stability of ${ }^{125}$ I-Zaleplon tracer along 8 hours without the detection of any by-products in the reaction mixture. Otherwise, storage of ${ }^{125}$ I-Zaleplon tracer for long time $(24 \mathrm{~h})$ causes a decomposition and the yield decreased to $75 \%$ which is not suitable for application in nuclear medicine.

Table 1. The in-vitro stability of ${ }^{125} \mathrm{I}$-Zaleplon tracerat optimum labeling conditions $(150 \mu \mathrm{g}$ Zaleplon, $150 \mu \mathrm{g}$ CAT, about 3.7 $\mathrm{MBq} \mathrm{Na}^{125} \mathrm{I}, \mathrm{pH} 4$, at $40{ }^{\circ} \mathrm{C}$ for $15 \mathrm{~min}$.)

\begin{tabular}{cc}
\hline $\begin{array}{c}\text { Time post } \\
\text { labeling, } \mathrm{h}\end{array}$ & $\begin{array}{c}\text { Labeling yield, \% } \\
\text { Mean } \pm \text { S.D }\end{array}$ \\
\hline 1 & $97.0 \pm 2.4$ \\
2 & $96.6 \pm 1.6$ \\
4 & $96.2 \pm 1.3$ \\
8 & $96.3 \pm 1.8$ \\
24 & $75.0 \pm 2.7$ \\
\hline
\end{tabular}

The presumable structure for ${ }^{125} \mathrm{I}$-Zaleplon via reaction of Zaleplon with $\mathrm{Na}^{125} \mathrm{I}$ in the presence of CAT as oxidizing agent is shown in Figure 6; where ${ }^{125} \mathrm{I}$ in the phenyl ring is in para-position. 
<smiles>CCN(C(C)=O)c1ccc(Br)c(-c2ccnc3c(C#N)cnn23)c1</smiles>

Figure 6. The presumable structure for ${ }^{125} \mathrm{I}$-Zaleplon

\subsection{Electrophoresis Analysis}

Electrophoresis analysis of the reaction mixture at optimum labeling conditions was indicated that ${ }^{125}$ I-Zaleplon is a neutral complex. This is due to the remaining of ${ }^{125} \mathrm{I}$-Zaleplon complex at the point of spotting. While the free iodide was moved $11 \mathrm{~cm}$ towards the anode, depending on its charge and ionic mobility (Attallah, 2002). These results are represented in Figure 7.

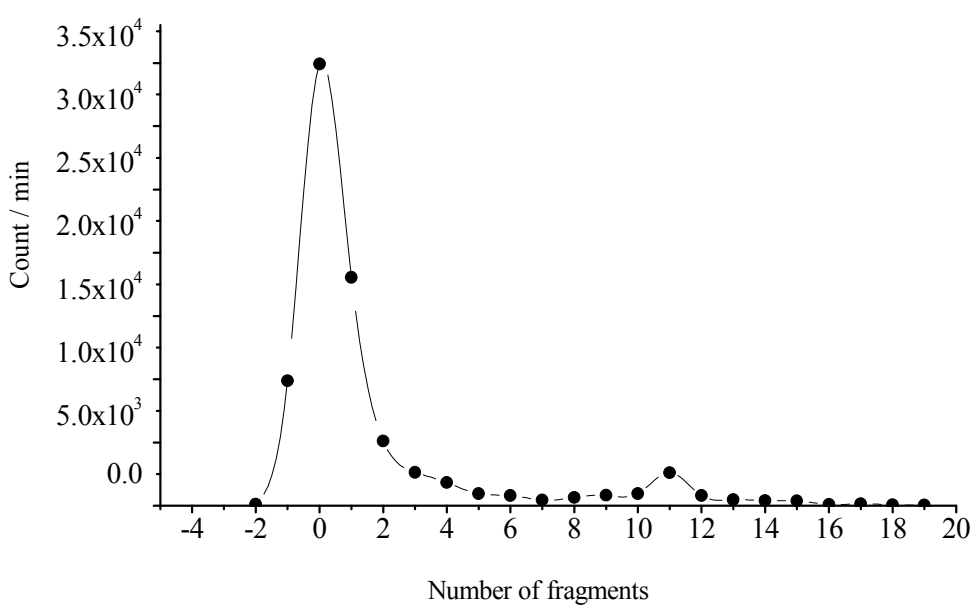

Figure 7. Electrophoretic pattern of 125I-Zaleplon complex at optimum labeling conditions ( $150 \mu \mathrm{g}$ Zaleplon, $150 \mu \mathrm{g}$ CAT, about $3.7 \mathrm{MBq} \mathrm{Na}{ }^{125} \mathrm{I}, \mathrm{pH} 4$, at $40^{\circ} \mathrm{C}$ for $15 \mathrm{~min}$.). Electrophoresis conditions: solvent: $0.2 \mathrm{M}$ phosphate buffer $\mathrm{pH}$ 7, paper type: cellulose acetate; $300 \mathrm{~V}$; running time: 90 minutes

\subsection{HPLC Analysis}

The reversed phase HPLC and methanol and water (70:30) system could be suitable for separate all the reaction species. Figure 8 illustrates the U.V. absorbance and the radio chromatogram of the reaction mixture. The species that were found during the labeling reaction are free iodide, Zaleplon, and labeled Zaleplon. These species were eluted separately as fractions and their U.V. absorbance showsthat iodide has a retention time $\left(R_{t}\right)$ of 3 min, that of labeled Zaleplon is $8 \mathrm{~min}$ and Zaleplon is $4 \mathrm{~min}$. The eluted fractions containing the labeled compound were pooled together. These collected fractions were evaporated to dryness. The residue was dissolved in physiological saline and then sterilized by filtration through $0.22 \mu \mathrm{m}$ Millipore filter, to give a specific activity of $15 \mathrm{MBq} / \mathrm{mg}$ of ${ }^{125} \mathrm{I}$-Zaleplon. The ${ }^{125} \mathrm{I}$-Zaleplon is then suitable for use in biodistribution studies. 


\subsection{Partition Coefficient for ${ }^{125}$ I- Zaleplon}

The partition coefficient value was $1.3 \pm 0.2$, showing that the ${ }^{125}$ I-Zaleplon is a lipophilic complex, so it has a rapid permeation through the blood-brain barrier.

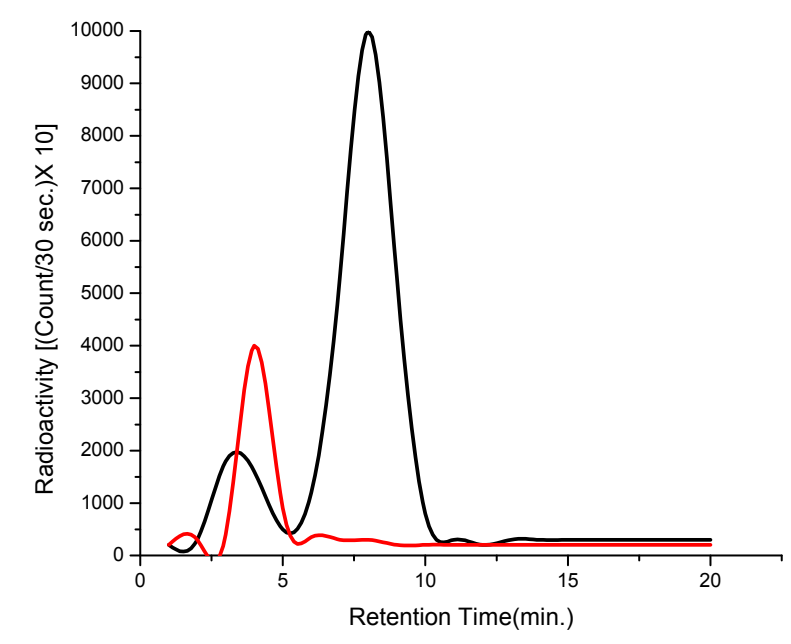

Figure 8. High performance liquid chromatography elution profile of Zaleplon, separated on reversed phase column nucleosil $(250 \mathrm{~mm} \times 4.6 \mathrm{~mm}, 5 \mathrm{~mm})$ at a flow rate of $0.5 \mathrm{~mL} / \mathrm{min}$

\section{Biodistribution}

The iodine-125-Zaleplon was injected into mice via intravenous to estimate its biological distribution. The data of this study is presented in Table (2), which shows a rapid initial distribution pattern. At 5 minutes post injection, high brain uptake was noticed (2.5\%/organ) indicating the ability of the tracer to penetrate the blood brain barrier (BBB) as fast as tracer injected. The clearance rate of the brain tissues was slow, referring to that the tracer bound to specific receptors in the brain. The blood elimination of the tracer was rapid and the time required to eliminate more than $80 \%$ of the total activity from the blood was 120 minutes. The elimination of the tracer from the mouse body was attained via two routes; the first one is the kidneys through which the main radioactivity was eliminated $(3.6 \%, 9.3 \%, 12.8 \%$, and $4.6 \%$ at $5,30,60$, and 120 minutes, respectively). The second route of tracer elimination was the liver, the total radioactivities detected in this excretory system were $2.8 \%, 6.1 \%, 7.3 \%$, and $2.9 \%$ at $5,30,60$, and 120 minutes, respectively) (Lake, Ball, Kao, Renwick, Price, \& Scatina, 2002). In respect to the radioactivity taken up by the brain and that in the blood per gram tissues (target to non-target), it is concluded that the ratio increased with time passes and reached to its maximum value of 2.3 at 120 minutes post injection. This was attributed to high clearance of the tracer from the circulation while low wash out from the brain tissues. 
Table 2. Biodistribution of ${ }^{125}$ I-Zaleplon in normal mice at different times

\begin{tabular}{lcccc}
\hline \multicolumn{1}{c}{ Organs \& body } & \multicolumn{4}{c}{ Time post injection, $\min$} \\
\multicolumn{1}{c}{ fluids } & 5 & 30 & 60 & 120 \\
\hline Blood & $29.5 \pm 1.2$ & $21.8 \pm 0.8$ & $16.0 \pm 0.5$ & $5.9 \pm 0.2$ \\
Bone & $4.5 \pm 0.2$ & $1.5 \pm 0.2$ & $1.6 \pm 0.1$ & $1.2 \pm 0.1$ \\
Muscle & $3.8 \pm 0.3$ & $2.7 \pm 0.4$ & $1.8 \pm 0.2$ & $1.0 \pm 0.1$ \\
Brain & $2.5 \pm 0.2$ & $3.8 \pm 0.1$ & $4.4 \pm 0.2$ & $1.9 \pm 0.1$ \\
Lungs & $0.5 \pm 0.1$ & $1.7 \pm 0.2$ & $0.8 \pm 0.2$ & $0.4 \pm 0.1$ \\
Heart & $0.5 \pm 0.1$ & $0.7 \pm 0.1$ & $0.6 \pm 0.1$ & $0.2 \pm 0.1$ \\
Liver & $2.8 \pm 0.2$ & $6.1 \pm 0.3$ & $7.3 \pm 0.3$ & $2.9 \pm 0.2$ \\
Kidneys & $3.6 \pm 0.2$ & $9.3 \pm 0.4$ & $12.8 \pm 0.4$ & $4.6 \pm 0.1$ \\
Spleen & $0.2 \pm 0.1$ & $0.9 \pm 0.1$ & $0.3 \pm 0.1$ & $0.1 \pm----$ \\
Stomach & $5.7 \pm 0.5$ & $10.6 \pm 0.4$ & $6.4 \pm 0.4$ & $3.3 \pm 0.5$ \\
Intestine & $4.7 \pm 0.4$ & $11.3 \pm 1.4$ & $8.0 \pm 0.9$ & $4.5 \pm 0.3$ \\
Urine & $4.2 \pm 0.2$ & $6.7 \pm 0.2$ & $18.5 \pm 1.2$ & $36.5 \pm 2.4$ \\
Feces & --- & $2.6 \pm 0.2$ & $8.4 \pm 0.5$ & $12.8 \pm 0.3$ \\
Thyroid gland & $0.7 \pm 0.1$ & $0.9 \pm 0.1$ & $1.1 \pm 0.1$ & $1.4 \pm 0.2$ \\
Brain* & $6.25 \pm 0.5$ & $9.5 \pm 0.2$ & $11.0 \pm 0.4$ & $4.75 \pm 0.2$ \\
Blood* & $10.5 \pm 0.6$ & $7.8 \pm 0.4$ & $5.7 \pm 0.3$ & $2.1 \pm 0.1$ \\
B/Bl, g & 0.6 & 1.2 & 1.9 & 2.3 \\
\hline "Injected & & &
\end{tabular}

*Injected dose / g tissue; B: Brain; Bl: Blood.

\section{Conclusion}

Most of the new radiopharmaceuticals are designed to bind specific neurotransmitter receptor or transporter sites in the central nervous system.Zaleplon was labeled with iodine- 125 using chloramine-T as oxidizing agent producing a radiochemical yield over $97 \%$. The labeling reaction was carried out in a wide $\mathrm{pH}$ range from 2 to 11. The in-vitro stability was investigated along 24 hours and the tracer showed good in-vitro stability during the first 8 hours. In addition, the in-vivo stability was ensured as the radioactivity taken up by the thyroid gland was 1.4 after 2 hours post injection. The in-vivo distribution of the tracer indicated the ability of the tracer to combine with specific receptors in the brain with late uptake equal to $4.75 \%$ and the $\mathrm{B} / \mathrm{Bl}$ ratio was 2.3 at $2 \mathrm{hrs}$.post injection.

\section{References}

Al dayel, O. A. F., Al Subybani, A. A., \& El-Garhy, E. A. (1989). Isotopenpraxis, 25, 489.

Attallah, K. M. (2002). Pharmaceuticalformulation,Radiochemical and biological evaluation of some iodine-125 labeled cytotoxic compounds as possible radiotherapeutic agents. (M. Sc. Thesis, Pharmaceutical department, Faculty of pharmacy, Zagazig University).

Barbera, J., \& Shapiro, C. (2005). Benefit-risk assessment of zaleplon in the treatment of insomnia. Drug Saf., 28(4), 301-18. http://dx.doi.org/10.2165/00002018-200528040-00003

Bolton, A. E. (1977). Rev. Radiochem. Center Amersham, 18, 1.

Damgen, K., \& Luddens, H. (1999). Zaleplon displays a selectivity to recombinant $\mathrm{GABA}_{\mathrm{A}}$ receptors different from zolpidem, zopiclone and benzodiazepines. Neurosci. Res. Commun., 25(3), 139-148. http://dx.doi.org/10.1002/(SICI)1520-6769(199911/12)25:3<139::AID-NRC3>3.0.CO;2-W

Dooley, M., \& Plosker, G. (2000). Zaleplon a review of its use in the treatment of insomnia. Drugs, 60, 413-445. http://dx.doi.org/10.2165/00003495-200060020-00014

Dundar, Y., Dodd, S., Strobl, J., Boland, A., Dickson, R., \& Walley, T. (2004). Comparative efficacy of newer hypnotic drugs for the short-term management of insomnia: a systematic review and meta-analysis. Hum 
Psychopharmacol. Jul, 19(5), 305-22. http://dx.doi.org/10.1002/hup.594

El-Azony, K. M. (2004). Arab J Nucl. Sci. Appl., 37, 81.

El-Azony, K. M., El-Mohty, A. A., Killa, H. M., Seddik, U., \& Khater, S. I. (2009). An investigation of the 125I-radioiodination of colchicine for medical purposes. J. Label Compd. Radiopharm, 52(1), 1-5. http://dx.doi.org/10.1002/jlcr.1556

Fei, L., He, Y. F., \& Luo, Z. (2004). IAEA, Austria, Technical Reports Series No 426, 37-52.

Heiss, W. D., \& Herholz, K. (2006). Brain receptor imaging. J. Nucl. Med., 47(2), 302-12. http://dx.doi.org/10.2165/00023210-199911050-00006

Hurst, M., \& Noble, S. (1999). Zaleplon. CNS Drugs., $\quad 11(5)$, 387-392. http://dx.doi.org/10.2165/00023210-199911050-00006

Knust, E. J., Dutschka, K., \& Machulla, H. J. (1990). Radiopharmaceutical preparation of $3-{ }^{123}$ I- $\alpha$-methyltyrosine for nuclear medical applications. J. Radioanal. Nucl. Chem. Lett., 144(2), 107-113. http://dx.doi.org/10.1007/BF02162193

Lake, B. G., Ball, S. E., Kao, J., Renwick, A. B., Price, R. J., \& Scatina, J. A. (2002). Metabolism of zaleplon by human liver: evidence for involvement of aldehyde oxidase. Xenobiotica. 32(10), 835-47. http://dx.doi.org/10.1080/00498250210158915

Noguchi, H., Kitazumi, K., Mori, M., \& Shiba, T. (2004). Electroencephalographic properties of zaleplon, a non-benzodiazepine sedative/hypnotic, in rats. J. Pharmacol Sci., 94(3), 246-51. http://dx.doi.org/10.1254/jphs.94.246

Patat, A., Paty, I., \& Hindmarch, I. (2001). Pharmacodynamic profile of Zaleplon, a new non-benzodiazepine hypnotic agent. Hum Psychopharmacol, 16(5), 369-392. http://dx.doi.org/10.1002/hup.310

Petzold, G., \& Coenen, H. H. (1981). J. Label Compd. Radiopharm, 18, 139.

Ramakrishnan, K., \& Scheid, D. C. (2007). Treatment options for insomnia. Am. Fam. Physician, 76(4), 517-26.

Shen, L. H., Liao, M. H., \& Tseng, Y. C. (2012). Recent Advances in Imaging of Dopaminergic Neurons for Evaluation of Neuropsychiatric Disorders. J. Bio. Med. Biotechnol., 2012, 259349. http://dx.doi.org/10.1155/2012/259349

Siriwardena, A. N., Apekey, T., Tilling, M., Dyas, J. V., Middleton, H., \& Orner, R. ( 2010). General practitioners' preferences for managing insomnia and opportunities for reducing hypnotic prescribing. J. Eval. Clin. Pract., 16, 731-7. http://dx.doi.org/10.1111/j.1365-2753.2009.01186.x

Siriwardena, A. N., Qureshi, Z., Gibson, S., Collier, S., \& Latham, M. (2006). GPs' attitudes to benzodiazepine and "Z-drug" prescribing: a barrier to implementation of evidence and guidance on hypnotics. Br. J. Gen. Pract., 56, 964-7.

Waghmare, A., Pore, Y., \& Kuchekar, B. (2008). Development and Characterization of Zaleplon Solid Dispersion Systems: A Technical Note. AAPS Pharm Sci. Tech., 9(2), 536-43. http://dx.doi.org/10.1208/s12249-008-9077-1

Wong, D. F., Gründer, G., \& Brasic, J. R. (2007). Brain imaging research: does the science serve clinical practice? Int. Rev Psychiatry, 19(5), 541-58. http://dx.doi.org/10.1080/09540260701564849

\section{Copyrights}

Copyright for this article is retained by the author(s), with first publication rights granted to the journal.

This is an open-access article distributed under the terms and conditions of the Creative Commons Attribution license (http://creativecommons.org/licenses/by/3.0/). 